\title{
The Role of Civic and Ethical Education in Democratization Process of Ethiopia: Challenges and Prospects
}

\author{
Tamirat Tadesse \\ Department of Civics and Ethical Studies, College of Social Science and Humanities, Wolaita Sodo University, Wolaita Sodo, Ethiopia \\ Email address: \\ tamirat64@gmail.com \\ To cite this article: \\ Tamirat Tadesse. The Role of Civic and Ethical Education in Democratization Process of Ethiopia: Challenges and Prospects. Humanities \\ and Social Sciences. Vol. 7, No. 2, 2019, pp. 49-57. doi: 10.11648/j.hss.20190702.11
}

Received: March 5, 2019; Accepted: April 23, 2019; Published: May 23, 2019

\begin{abstract}
The objective of this study is to investigate the role of Civics and Ethical Education in building the process of democratization in Ethiopia as well as the challenges facing in implementation process of the discipline and its future prospects. This study is mainly an empirical research focusing on the practical experience of researcher and different secondary sources of data were employed. Methodologically, qualitative research approach was employed to achieve the stated objectives. Accordingly, secondary sources such as journals, books, policy documents and reports were employed for this study. To substantiate the data gathered through secondary sources, primary source of data was also employed like observation of the researcher and key informant interview were used in this study. Based on the data analyzed the finding of the study shows that Civics and Ethical Education has played prominent role in the democratization process of the country. Especially, the discipline has created the demanding society in general and created the youth who knows their rights and demands their human and democratic rights to be protected. The study has shown Civics and Ethical Education has progressive role than previous type of Civics Education existed in the country; but still the gap with regard to creating responsible citizens those who knows their duties (responsibilities) and rights are interdependent. Finally, the study has indicated about challenges facing in implementing the discipline and its future prospects.
\end{abstract}

Keywords: Civic Education, Civics and Ethical Education, Democratization, Ethiopia

\section{Introduction}

Education is one of basic element of development of a given country. The educational development in Ethiopia is not as old as the history of Ethiopian state. Education in general and Civics and Ethical Education in particular play great role in democratization process of one country. Civics and Ethical Education is one of the recently growing disciplines in Ethiopia having the objective of creating selfdisciplined, responsible, active and informed citizen in the country. It is the discipline incorporated with the curriculum and offered to students in different levels of education in Ethiopia under the guidance of ministry of education. The discipline is concerned with teaching students about democracy and democratization, human right, constitution and constitutionalism, and other basic concepts of democratic institutions and democratic state. It is taught in Ethiopian schools and higher education since the emergence new education and training policy in the country.
Ethiopian regimes taught Civic Education in their time of governance, having different objectives and goals in the country. The most known type of Civic Education in the country in three successive governments is Moral Education in imperial regime, Political Education in military regime and Civics and Ethical Education in current government of the country. Following the transition from long stayed unitary to federal structure of the state in the 1990s, attempts have been made to institutionalize the protection of human and democratic rights of citizens; and also a popular constitution was set in place in 1995. Based on NETP (New Education and Training Policy) to further enhance the ideals of democracy and democratization process, Civics and Ethical Education was introduced into the education system. In the quest to consolidate the democratic process in the country and enlighten citizens in their rights and obligations, since 2002/03 the curriculum of civic education was revised and a new Civics and Ethical Education curriculum, which is based on major social values, is adopted across the grade levels. 
This clearly shows the intention of the government to create peace loving, tolerant, and vibrant generation even in the earliest days of its rule [12].

This study assesses the role of Civics and Ethical Education in the process of democratization in Ethiopia including the challenges and prospects. The goal behind teaching of Civics and Ethical Education at different levels of education is to create democratic and responsible citizen in the state. The current government of Ethiopia has come up with the discipline to inculcate democratic culture in its citizens. The discipline has been offered to students in different levels of education with the intention of creating good citizens equipped with virtuous characters who are actively involving in the overall public affairs of the country [3].

Nevertheless, there is no comprehensive study has been conducted regarding the role of Civics and Ethical Education in the democratization process and to accomplish the intended objectives. The studies conducted are insufficient in addressing the objectives and challenges of the discipline. Therefore, to fill the gap, the researcher has conducted this study where the objective of the study is to investigate the role of Civics and Ethical Education in building the process of democratization in Ethiopia as well as its challenges and future prospects. To achieve the stated objective the researcher has employed qualitative method of research. For this purpose secondary sources like books, journals, government policy documents and published and unpublished documents were employed for this study. To substantiate secondary data, the researcher employed Primary data like observation and key informant interview as a tool of data collection.

This study could benefit various stakeholders as well as the community at large. Different stakeholders working on this issue could be benefited from the study like policy makers, civil society, schools and higher education institutions. This study could be a benchmark for further study and therefore, governmental and Non-governmental organization will use it for better advancement of society.

\section{Conceptual Clarification of Civic Education}

Civic education has got attention by the government of Ethiopia, because it plays key role to build democracy and enhance prosperity $[10,11]$. Civic education in a democratic society aims at producing informed, competent and responsible citizens by equipping them with civic knowledge, civic skills and civic dispositions so that they can effectively participate in the political, social and economic affairs of their society. The discipline has two interconnected concepts which include the concept of Civics and Ethics. Civics is defined as the branch of social science that deals with the rights and duties of citizen. As it is noted in [8], Civics is mainly a study of government and means of administering the interest of the people, or theory of governance as practiced to public institutions with respect to their relations to the public.

The history of Civic Education dates back to ancient theories of citizenship in ancient Greek. The word Civics is derived from Latin word "civitas", which means citizen or of citizen. This in turn leads Civics as a discipline of knowledge dealing with everyday issues of the state and its citizen. Civics claims that every individual should be aware of his rights, duties and social responsibilities to establish good society [8].

"Civic Education is learning for effective participation in democratic and development processes at both local and national levels. It is an important means for capacity development on the societal level by empowering people for effective civic engagement. It is an essential dimension in strengthening a society's ability to manage its own affairs and is complementary to capacity development on the individual and institutional levels." [17].

As [18] cited in [3], Civic Education is offered to citizens in different countries with different nomenclatures. Names like Civic Education, Citizenship Education, and Civic Engagement, Education for democratic citizenship, Civic Culture, Political Education, and Moral Education are among the names which are used in different countries with no difference with regard to the goal and objective of the discipline. All names stated above which are implemented in different countries with the goal of promoting and developing civic culture.

According to [8], Civic Education is a branch of social science which is concerned with the human character, tradition, political association, mutual relations of state. Civic Education involves the knowledge and the development of intellects about the contents of Citizenship Education [12]. It involves basic knowledge of the political system and its operation, the physical geography of the country and its people; the history of the country and its peoples; the economic system and its workings; and current issues.

\section{The History of Civic Education}

The history of Civic Education goes back to ancient Greek city state of Athens. The emergence of Civic Education is the same with the existence of democracy. One can consider that Athens is the origin of Civic Education as well as democracy. Therefore, we can consider that both of them have the same root of beginning. The education system in Athens encouraged the development of responsible citizen and laid foundation for modern education systems in different countries [8]. In medieval Europe, the so called citizenship education, the then civic education, is offered to students in religious institutions mainly, because, in medieval period, state and religion are bonded together and there is supremacy of church over the state. Thus, state and church were partners in every aspect like economic, social, education issues; Civic Education is given along with religious education.

During the time of renaissance, the rebirth of civilization and enlightened concepts aroused in Europe, and the church 
lost the dominance over the state, and this paved the way for secular education including Civic Education. Consequently, the rise of revolutions in Britain (1688), France (1789) and America (1776) contributed its part for the development of democracy in general and enlightened concepts, and the revolution further played its role for the development of secular Civic Education in particular in Europe and other world [3].

The discipline became more popular in 1990's as one of crucial element to promote democracy and to create responsible and democratic citizen. Different factors influenced the emergence of modern Civic Education in many countries. For instance, in United States of America, modern Civic Education is incorporated to formal educational system in 1916 [8].

\section{Civic Education in Ethiopia}

The experience of Civic Education in Ethiopia varies from regime to regime. Studying the experience of Civic Education in Ethiopia goes back to imperial regime of Haile Sellasie I. Civic Education was started to be offered to students in formal educational system in the time of imperial regime with the name of the subject called "Moral Education". The basic objective of teaching moral education was to build the character of students according to orthodox Christian faith to instill obedience and sense of sub service in the younger generation so that they could remain compliant to the prevailing political, social and economic order [6]. Therefore, Moral Education of the time was not centered on developing civic culture, in creating responsible and informed citizen as well as in building democracy in the state.

After the demise of imperial regime, in Ethiopia the military regime took power in 1974. This government had adopted the political philosophy of Marxist-Leninist ideology. The government designed different policies in line with the concept of socialism. One of the policies which are designed in line with socialism was education policy. Within that education policy, the government started to teach Civic Education with notorious name called "political education". The objective of teaching political education was mainly indoctrination or instilling the concept of socialism and proletarian internationalism. As compared to imperial regime, Civic Education in military regime was secular education, which emphasized on ideological orientation of the regime called Marxist-Leninist ideology [9] but still it is simple ideological education not as such democratic civic education. It does not give room for democracy and democratization process rather military dictatorship government stayed in power for around two decades in the country.

The type of Civic Education which existed in imperial and military time was not as such democratic Civic Education which builds democracy, human right, basic freedoms and duties of citizen. Rather, Civic Education at that time was an instrument to strengthen the ruling system of the existing government and accepting the government system as it is. In both regimes, Civic Education did not include the concepts of democracy, human rights, justice, equality, freedom, liberty and so forth. [8] Noted that, Moral Education and Political Education in two consecutive regimes should not be considered as democratic Civic Education because of there is no content which is related with Civic Education and both regimes did not solve the problems of freedom, rights and responsibilities of citizens. [16] cited [9], both of moral and political education at that time was to develop inequality and oppression on the country.

After the end of Derg regime in 1991, Ethiopian People's Revolutionary Democratic Front (EPRDF) took power in Ethiopia and introduced the new curriculum of Civic Education having unique objectives from its predecessors. The current Civic Education is better than the previous Moral Education and Political Education with regard to its contents, methods and objectives. The current Civic Education is emphasized to equip students with the knowledge of democracy, human right and freedom, equality and justice, citizenship and morality, constitution and constitutionalism and so forth. Based on this it is better Civic Education during current government than previous regimes. [19] cited in [9] argue that, after the downfall of military regime, the government who took power gave attention for democratization and designed Civic Education which gives due attention for democratic contents.

The current government of Ethiopia introduced the new citizenship education with the official name of Civic and Ethical Education in line with new education and training policy (NETP) which is developed to promote democracy, equality, rights and duties of citizen, social justice and tolerance in the country. Post-1991, policy of education was designed to achieve new national, political, economic and social objectives of the country. The current government has worked tiresome work to make education to answer different requests related with democratic national unity [3]. [8] Stated that, current Civic Education is major departure from previous curriculum with regard to contents, objectives and methods.

Developing the new curriculum of Civic Education was started before the official inauguration of the constitution of Federal Democratic Republic of Ethiopia (FDRE) of 1995. After two years of EPRDF took power, the government designed the curriculum of Civic Education and started to teach students in high schools. At first, the discipline was called Civic Education and in 2000, the curriculum was revised and renamed as Civics and Ethical Education and offered to students in primary, secondary, colleges and universities with intentions of creating active, informed and responsible citizen and to play its part in democratization process of the country [19].

To promote the effectiveness of Civics and Ethical Education, the FDRE Ministry of Education has taken different measures so far. Of these measures, one is measure regarding curriculum revision. There were three major periods of curricular change. The first period was, of course, when the subject was introduced. According to the first 
curriculum, the mission of Civics and Ethical Education is to help students to be competent Ethiopian citizens endowed with a global and human outlook, strong and democratic national feelings and sense of patriotism; to develop democratic values and the culture of respect for human rights; to stand for truth and the well-being of the peoples of Ethiopia as well as for equality, justice, and peace; to understand, apply, and uphold the Constitution [19].

\section{Objectives of Civic Education in Ethiopia}

The objective of teaching Civic Education in Ethiopia is mainly characterized with different aspects:

Firstly, as [13]cited in [3], the main purpose of Civic Education is creating good citizen who has capacity of intellects to critically analyze ideas, who actively involves in civic life (including political life) has a wonderful character and who seriously cares about the wellbeing of other citizens. In addition to that [3] noted that Civic Education helps students to determine what rights they are trusted with and which responsibilities they are expected to discharge in their country. Hence, they can easily entertain their rights and discharge their responsibilities as well as respects the rights of others which would lead to its contribution in creating democratic citizen and plays its part in the human development of the country.

Secondly, teaching Civic Education as [8] stated is to develop the skill of participation that influences in the formulation, implementation, interpretation of the public policy of the country as well as taking part in solving different community problems and involving in different voluntary associations for the benefit of societal development. In this sense, Civic Education is mainly to equip students with the skill of involving in different public affairs. According to [18] cited in [3], the good citizen is the one who is equipped with appropriate knowledge, skills and traits of character which are instrument for the good of the public. This shows that, Civic Education has its role in building democracy and democratic citizen, since participation is one of the pillars of democracy.

Thirdly, as it is known that, Ethiopia is the country where there is full of diversity in the country. The country has multi-lingual and multicultural setting, so that developing the culture of tolerance and respect is essential for peaceful coexistence of the society. Civic Education is teaching students about how to live with in diversity and mutual co-existence. Therefore, it is designed to teach students about accommodating diversity and to capitalize tolerance in the country.

Finally, in Ethiopia Civic Education is not only equipping citizens for better political life and democracy alone, but also the discipline has another integral part called Ethics. Where, it focuses on creating a citizen who is morally good, who respects the social values of the society, who tries to be just and impartial in his life and tries to be ethical in with the relation to others and being virtuous citizen is another important objective of Civic Education.

\section{Civic Education and Democracy}

The concept of Civic Education and Democracy has the same root of beginning. Both concepts were emerged in ancient Greek. The first Civic Education is emerged in ancient Greek city state of Athens and the concept of democracy was also emerged in ancient Greek. As [8] noted that, Civic Education is considered as political engagement, to be a citizen means to be a politician. Hence, it is considered as one of the important tool for democratization process in Ethiopia by inculcating basic concepts of democracy, by creating active, responsible and informed citizens.

Civic Education and Democracy are interrelated issues but they are not complementary to each other. This means one cannot be a prerequisite for the other; democracy can exist without Civic Education and Civic Education can exist without democracy. In one country, the government can teach Civic Education to its citizens but this is not the indicator on prevalence democracy. This is what happened in Ethiopia during imperial and military regimes where the regimes had taught moral and political education during the time of governance but it does not incorporated the issue of democracy and democratic principles; never indicated the prevalence of democracy in the country. The current regime is also criticized with regard to handling of democracy and human right issues; even though there is better Civic Education exists than before. Better in essence it included basic issues of democracy, human rights, constitutionalism and other basic concepts that democratic civic education shall comprise. Therefore, teaching of Civic Education will promote and enhance the process of democratization in one country; this does not mean teaching of Civic Education is precondition for the prevalence of democracy.

\section{The Success of Civics and Ethical Education}

Ethiopia is one of the countries in the Horn Africa with fast growing economy and large population in the region. The history of the country in the process of democratization is recent issue and not more than decades. The country has passed governments which frequently, violates democratic and human rights in the state. After the demise of military regime in the country, EPRDF government comes up with the promising ideas to democratize the country and to institutionalize the process of democratization.

The country Ethiopia has large number of youth population which is employed in education sector. This large number of population is responsible for the socioeconomic and political development of the nation. To build the country by responsible and informed citizen, Civics and Ethical Education is considered as a tool in the process of 
democratization in the country. The government of Ethiopia believes that teaching Civics and Ethical Education in formal educational system would play its role in creating democratic, responsible and informed citizens and this in turn have its role in the democratization process of the country.

In the process of democratization, teaching of Civics and Ethical Education has its own role but it is not a prerequisite (not sufficient) condition for the prevalence of democracy. It teaches about the concept of democracy, human right, constitution of the state, government, election, Ethics and Civic Virtues. It prepares the youth of the country to take part through the knowledge they acquired, in different public affairs of the state. Citizen's participation in different public affairs is one of the principles of democracy and plays its main part in democratization process and development of the state.

Civics and Ethical Education played its part in maintaining multiculturalism in Ethiopia. The country is known by its diversity with regard to language, religion, culture and ethnic groups. It enabled students to celebrate and promote diversities (multiculturalism) of nations, nationalities and peoples of Ethiopia [19]. [7] Also noted that, it helped students to acknowledge the cultures of others of nation, nationalities of the Ethiopian state.

The incumbent government adopts Civics and Ethical Education as an instrument to inculcate democracy, human right and basic political issues to citizens. This is because the participation of people, in democracy is very important in building democratic system in the country [19]. Recently, Civics and Ethical Education is creating a citizen who requests their constitutional rights and demanding reform regarding the policies and decisions of the government.

Civics and Ethical Education is playing its pivotal role in enabling popular participation. It is known that popular participation is one of the pillars of democracy and democracy cannot be sustainable unless, popular participation is encouraged. Vibrant popular participation needs adequate civic knowledge, skill and attitudes of citizen because the more skillful and knowledgeable citizens are the more active participants [9].

As it is cited in [9] in this aspect, Civics and Ethical Education has been contributing in producing citizens with necessary civic knowledge, skill and dispositions which enable them to be active participants in the political, economic and social affairs of their country. As far as the participation is concerned, a research conducted by USAID in 2002 found citizens who learned Civic and Ethical Education are better in democratic participation in election, political decision making and paying tax than those who do not learn. Citizens in non-democratic countries do not have the required elements of citizenship and morality. Thus, the best solution for citizens who do not have the desired civic knowledge, skill and dispositions is teaching Civic and Ethical Education because it helps them to be active participants in addressing societal and political problems of their country.
Since 2015, after general election was conducted in Ethiopia, the country has passed different protests and movements in different part of the country. In this general election, the ruling party the so called EPRDF the coalition of four ethnic based groups from four regional governments has won $100 \%$ of seat in the parliament. After general election was conducted and the result of election was publicized, the dissatisfaction of the people was outbreak in some parts of the country. The youngsters in different part have protested against the ruling party in power and the rebel was spread to different part of the country. The protest was requesting the rights and freedoms of the people should be respected and good governance shall be realized and the room for democratic participation should be open.

The response of the government becomes arresting peaceful protesters, brutally attacking individuals who protest the government in power. This irresponsible use of power and violation of human rights and freedoms led to the statewide protest in the overall country. The youth continued asking individual rights which were guaranteed by the constitution of the country shall be respected and the government has responsibility and obligation to respect and protect the constitutional rights of citizens.

After serious of movements and protests, the ruling government was forced to take reform in political system of the country. The political executive of the country and chairman of the leading party has decided to resign from power. The decision of the government was to take numerous reforms in the country including all political prisoners should be released, rule of law shall be declared, abusive laws shall be revised and human and democratic rights guaranteed by constitution shall be protected.

Finally, the ruling government came with the new prime minister and peaceful power transfer has been taken place in the history of the country. The new prime minister took different political measures in the country to satisfy the interest of the people. Political reforms taken by the new government were releasing political prisoners, allowing insurgent groups to come to the country to run peaceful dialogue, opening closed medias and websites, amending repressive proclamations in the country were among the major reforms that the government has took.

This all protest and movement in the country were run by the youth population of the country who learnt civic and ethical education. This shows that, the youth who learnt Civics and Ethical Education became questioning generation, who does not pass injustice and violation of rights and freedoms. This indicates that Civics and Ethical Education has played its role in widening the knowledge toward governance and to request rights to be enforced. At the same time it made the youngster to wake up from suppression and lack of good governance which are deeply prevailing throughout the country. Therefore, the discipline Civics and Ethical Education created demanding society in general and wants to involve in public affairs of the society. 


\section{The Challenges of Civics and Ethical Education in Ethiopia}

Although, Civics and Ethical Education in Ethiopia has played different roles in building democracy and creating responsible citizen in the country, there are also many challenges which are facing in implementation of Civic and Ethical Education in teaching learning process. According to [3], notwithstanding its contribution in building democratization process and building the moral behavior of the youth the success is not enough. There are different factors which limit the effectiveness of the existing goals of Civics and Ethical Education. The following factors are among the challenges that universities and schools are facing in the process of implementing the discipline.

\subsection{Attitude and Perception for Civics and Ethical Education}

Historically, as it is described on the experiences of Civic Education in Ethiopia in imperial regimes, moral education was used as an instrument to teach students about the divinity of the emperor and in derg regime political education was indoctrinating the ideology of the government to the students. From this experience, the public considers today's Civic and Ethical Education is the same as the past which is indoctrination about the leading philosophy of the government.

This perception is not only from the student but also teachers, family; the school leadership relates Civic and Ethical Education as simply teaching the political education in the country. The source of the problem is wrong attitude of political education but the question is whose political education it is? However, Civic and Ethical Education is the political education of the state. This is because; it is an education which deals mainly with the political and legal aspects of the country. It teaches citizens about the constitution, rights and freedoms of citizen as well as the democratic system of the country, which indicates the political nature of the subject [9]. Moreover, the historical legacy of the political education of the military government has great impact on the current Civic and Ethical Education. The study made by [5] noted that at present the subject teachers have faced difficulties from both sides. The first challenge they face is from the government side. The government looks the subject teachers as threats of the regime from the perception that teachers are biased to the FDRE constitution rather they try to promote their ideology upon their students. The second challenge civic and education teachers' face is from the society; the society perceived the subject teachers as cadres of the ruling party or individuals assigned to indoctrinate the subject.

\subsection{Content and Context Related Challenges}

The curriculum lacks major points which could be included in the curriculum in different grade levels. Basically, the social values, morality and ethics are ignored in the Civics and Ethical Education curriculum in secondary levels. The subject by itself is Civics and Ethical Education, but it disregarded and undermined ethical aspects and societal values. The ethical issues and societal values were marginalized by the curriculum of Civics and Ethical Education in secondary education level. The context ethical education tries to teach students about morality is all scientific moral philosophy. It does not give room for indigenous moral values that society has developed a number of social and moral values through time. Therefore, indigenous social values and philosophy is undermined and not given emphasis; this led the youth to lose the social values where living and dominated by western culture.

\subsection{Shortage of Professionals}

Civic and Ethical Education in Ethiopia is the recently growing discipline which is young science that was incorporated to the curriculum of the country. In Ethiopia, before a decade there was no higher institution which trains students in Civics and Ethical Education profession in the country. There is no doubt that teachers of Civic and Ethical Education have great role in creating ethical, rational, active, responsible and democratic citizens who could play their critical role in building of democratic system in the country. Trained professional teachers are major actors to achieve the goal of the subject. For this purpose, currently, the Ethiopian government is committed to produce trained professionals of Civic and Ethical Education teachers. Besides, it is not more than a decade that higher institutions throughout the country have opened Civics and Ethical Studies at Department level to fulfill the acute shortage of trained personnel in the area of the study [9].

However, Civic and Ethical Education has been taught by teachers of other disciplines in schools and universities for long period of time. Most of the teachers who are involved in teaching Civics and Ethical Education are graduates of History, Geography, Political Science, Philosophy, Law, public administration, were among the teachers who teach Civics and Ethical Education in high schools and universities. The study made by [5] stated that, other discipline teachers are forced to teach a course, which is not professional because of low perception toward the discipline. For this factor, the real contribution of Civic and Ethical Education in creating active, participant citizen and having good ethical behaviors is limited due to lack professionals on the area.

\subsection{Lack of Role Model Teachers}

Civic and Ethical Education teachers are expected to be role model teachers for students because they are teachers of morality and behaviors. If Civics and Ethical Education teachers are not living with what they are teaching, we call it they are not role models for their students. In schools and universities teachers should be role model for their students because students should consider their teachers as their model but what we are looking is teachers are not becoming 
role models for their students. It has been described that teacher quality is therefore basic and has been globally recognized to be mainly related with the quality of education in general and the outcome of students' learning in particular [3].

Therefore, to transfer knowledge and to enhance the understanding of students; attitudes, skills, learning, and core values, teachers should have the competence. It is also affirmed that "they are role models within themselves for their students who, consciously or subconsciously, emulate their behavior" [3]. Therefore, teachers should mold good behavior for their students. However, it is familiar to see Ethiopian teachers are not motivated because of low morale due to inadequate salaries, low respect for the profession and status of teachers, and poor management and leadership [3]. This, in turn, adversely influences the proper role that teachers are expected to play in providing quality education and building good character and civic virtues.

\subsection{Lack of Structure to Follow the Progress}

The discipline needs follow up in the progress of character of students. In Ethiopia, the discipline is mainly concerned with creating awareness about rights, responsibilities, and obligation, constitution and governance related issues. In addition to that, it is also concerned with building good character, disciplined and responsible citizen. Therefore, for the success or the achievement of the objectives there shall have the structure in schools and universities that follows the progress of the character of the youth through various mechanisms. But in universities and schools, there is no structure that follows the progress as well as the change of behavior of students through education. The subject is about developing skills but it emphasized on simple development of knowledge without applying the knowledge acquired.

\subsection{Environmental Factors}

The behavior of students is designed by their peer, family and community at large; their behavior is not only formed in the school. Simply teaching Civics and Ethical Education is not enough to create ethically and morally responsible citizen. According to [3], there are many factors which have great impact in shaping behaviors of students. For instance, the influence of peer, family, neighbor and community play pivotal role in shaping students' behavior. When their peers are actively engaged in harmful practices such as using drugs, alcohol, smoking cigarette, and chewing chat, they likely engage in similar activities.

Students are taught the good characters of a citizen in class such as tolerance, honesty, integrity, responsiveness, civic and open mindedness and compassion. However, they are easily exposed to corrupt persons in and out of school, which have negative impact on their character as [1] cited in [9]. Hence, it is expected to enable environment to meet the objectives of Civic and Ethical Education [3]. In addition, students are taught democratic and constitutional values in class. However, when they go to the external environment, most of the time they do not observe the democratic and constitutional principles and values are practiced on the ground.

\subsection{Improper Mode of Delivery}

Civics and Ethical Education is designed to enable student's active participant in public affairs as well as to be critical thinkers. To make students to be active participant, it is better to find the proper way of delivery. There are different types of pedagogical approaches for teaching Civic and Ethical Education.

The study conducted by [2] also indicated Civic and Ethical Education needs to be rehearsed often and be interactive and participatory. Participatory and interactive approaches such as role playing, problem solving and discussions are better to be conducted to have proper way of delivery.

However, according to the study conducted by [5] and as the researcher observed and experienced with the discipline, most of the time the subject is delivered through lecture method. The mode of delivery of lecture is prevalent at all primary, secondary and tertiary levels. [3] Cited in [9] indicates that, lecture method is not appropriate method with the nature and objectives of the subject. For example, teaching Civic and Ethical Education with plasma television affects students from acquiring the desired civic knowledge, skill and dispositions [16] cited in [3] because of being it is too fast, beams once, dependent on the flow of electric power, and language barrier only in English language with no local language support [15] cited in [3]. This method of delivery compromises the goal and objective of education at large and Civic and Ethical Education in particular. Therefore, allowing students to discuss each other and to involve in learning by understanding the concept with their teachers will enable them to internalize the Civic and Ethical values and to exercise them in their classrooms.

\subsection{Deficiency of Democracy}

[17] Has stated that, the government has crucial role in teaching Civics and Ethical Education and the government should create conducive environment to strengthen democracy in the country. It is the government that plays pivotal role in building civic dispositions of students. [17] Has revealed that, it is useful that government should not be taken just as potential player but as crucial actor, the disposition of which will have valuable influence on the knowledge of civic education programme to function and produce results. In line with this, the government should make sure that the system is functioning and basic freedoms like freedom of speech, expression, and assembly are recognized. The interests of the society as well as civil societies working on the civic issues should be emphasized and resources shall be mobilized for this purpose.

The prerequisite of Civic and Ethical Education are better satisfied in a state having strong democracy. However, Ethiopia has infant democracy which lacks basic democratic 
institutions and its implementation is sluggish which in turn hinders the proper realization of the goal of Civics and Ethical Education [1]. When there is good environment for democracy citizens want to participate in various issues and the government should be democratic and the environment shall be enabling environment. If it is deviant with the theory they developed they can consider all is fake democracy is also considered as pseudo democracy [3].

\subsection{Improper Understanding of Rights}

One of the achievements of Civics and Ethical Education is it has created demanding society that asks basic rights to be effective and implemented. But there is a gap of the youth of the nation in discharging their responsibilities as they are claiming of their rights. In this aspect citizens learnt about rights and responsibilities or obligation equally. Where rights and responsibilities are interdependent and all claims could not be the right. But in Ethiopia, there is the gap with regard to discharging one's own responsibilities unlike claiming for their rights. The challenge is that the youth tries to enjoy the basic rights without discharging the expected responsibilities. Such gap will be filled through working together with government, civil society and other concerned stakeholders in creating awareness as the rights and responsibilities are inseparable.

As stated in [13] students in school are not good at shouldering responsibility and their understood rights without understanding responsibilities. The situation in school is changing from good quality to bad; the students today do not want to do anything for the school and for teachers. The new education system was come up to talk our backwardness and poverty so as to facilitate our prosperity. From the lower level up to the higher level graduate, the students are becoming selfish, irresponsible, unmotivated to discharge their responsibilities. When we come to our students, they were really selfish. They always run to protect their rights without caring out their responsibility. They were very serious for pieces of their rights. But they are negligent for their responsibility.

\section{Prospects and Opportunities of Civic Education}

Civic and Ethical Education has a number of challenges which have been faced limits effectiveness of the discipline. But this does not mean that the discipline lacks opportunity and prospect in the country. Based on the success history and achievements, there are various opportunities and prospects are seen from Civics and Ethical Education. Having this in mind, the Federal ministry of education of Ethiopia is working to reform the education curriculum via new road map of the country in general and Civic and Ethical Education in particular to improve its effectiveness by considering the gap.

Civics and Ethical Education has various opportunities and prospects regarding building moral values and peace in the country. The discipline focuses on creating a peaceful community which lives in multicultural setting and peaceful co-existence. It also cultivates student's character positively by teaching about morality and also enables them to discharges their responsibilities to the best of their capability. It created an opportunity to appreciate and recognize the cultures and ways of life of nations, nationalities and peoples of Ethiopia. At the same time, it created an opportunity for students to develop knowledge and skill about active community participation in public affairs [7].

Civics and Ethical Education is a course that develops and promotes civic skills, knowledge and disposition to affirm both changes in behavior and attitude of the learners. It also promotes cohesion and harmony among learners in the sense that it create conducive environment to co-exist with other socio-cultural groups and have a culture of respect for the view of one another. Besides, it also enforces the students so as to develop culture of hardworking due to the fact that it discusses issues titled patriotism, responsibility, industriousness and self-reliance. These issues are more closely related with character development and moral education [19].

MOE (Ministry of Education) in collaboration with different stakeholders are working to strengthen the role of Civic and Ethical Education in public affairs of the country. Among the basic prospects expected are Civics and Ethical Education has to play in creating peaceful citizen and strengthening democratic outlook. Teaching of Civics and Ethical Education aimed at generating political consciousness in the students and inculcate democratic outlook in the souls of the students. For the country's young democracy, a study of Civics and Ethical Education can help a lot to develop proper attitudes in students, which can ultimately strengthen democracy, to build national consensus and harmony in the country [7].

\section{Conclusion}

1. The discipline Civics and Ethical Education is crucial discipline for the development of democracy and democratization in the country Ethiopia. At the same time, it has vibrant role in creating awareness to the youth to involve in the political environment of a given country. The discipline works to create responsible, active and well informed citizens to the state who participates in the public affairs of the country. Moral and political education of imperial and military regime respectively failed to achieve the role expected from civics and ethical education.

2. The current civic and ethical education contributed its part in building democracy and in building ethical behavior of citizens. It also created a chance for students to know their rights, duties and responsibilities in their public life. This does not mean that there is no gap in the discipline rather the study showed that there are a number of challenges which limits the effectiveness of civic and ethical education in the public 
life. Among the challenges the study has described are like content and context related challenges, attitude and perception toward the discipline, environmental factors, lack of structure to follow up, lack of role model teachers, insufficient democracy etc. are among the challenges that limits the role of civics and ethical education in democratization process of Ethiopia.

3. In addition, to that civics and ethical education has created opportunities to students to acknowledge the culture, tradition and language of nations, nationalities and peoples of Ethiopia. All stakeholders are expected to be committed for the effectiveness of the discipline especially, government, community, student, teachers are mainly responsible to limit challenges while implementing the discipline.

\section{References}

[1] Birhanu Jibril (2012)."The Role of Civics \& Ethical Education in the Development of Students Behavior: the case of Kokob Tsibeha Secondary \& Preparatory school", Unpublished MA thesis, Addis Ababa University, Ethiopia.

[2] Browne E, (2013) "Civic education: approaches and efficacy", GSDRC helpdesk research report.

[3] Endalcachew Bayeh (2016). "Role of civics and ethical education for the development of democratic governance in Ethiopia: Achievements and challenges", Pacific Science Review B: Humanities and Social Sciences 2 (2016) 31- 36.

[4] Federal Democratic Republic of Ethiopia (1995). “The Constitution of the Federal Democratic Republic Government of Ethiopia", FDRE, Negaret Gazetta.

[5] Federal Democratic Republic of Ethiopia (2017) "policy study and research center report" Addis Ababa.

[6] Fetene Bulcha (2017). "The Role of Civics and Ethical Education in Shaping Attitudes of Students: The Case of Jimma College Teachers Education", Global Journal of HUMAN-SOCIAL SCIENCE: Publisher: Global Journals Inc. (USA) Online ISSN: 2249-460x \& Print ISSN: 0975-587X Volume 17 Issue 2.

[7] Gosa Setu and Desta Tamrat (2014). "The Roles of Civics and Ethical Education in shaping the attitude of the students in higher education the case of Mekelle University" Journal of Education and Practice ISSN 2222-1735 (Paper) ISSN 2222288X (Online) Vol.5, No.30, 2014.
[8] Meron Tilahun (2006). "Civic education \& students of higher learning: a case study. In: Proceedings of the Fourth National Conference in Private Higher Education in Ethiopia", St. Mary's University College, Addis Ababa.

[9] Micheale Kihishen (2017). "Civic and Ethical Education in Ethiopia since 1990s: Achievements and Challenges", Journal of Citizenship and Morality Vol.1, No.1, November, 2017, 78105 .

[10] MoE (2003). "Civic and Ethical Education", Grade 11 Student's Textbook. (EMPDA) educational materials production distribution agency, Addis Ababa.

[11] MoE, (2003), "Civic and Ethical Education: Grade 9 Student's Textbook", EMPDA, educational materials production distribution agency Addis Ababa.

[12] Mohamed Yimer (2017) "Civic And Ethical Education In Institutions Of Higher Learning In Ethiopia; Challenges, Opportunities And Policy Implications". International journal of scientific and technology research.

[13] Mulalem Yohannes, Fitsumbirhan Tewelde, Fitsum Abrha (2017). "The Role of Civic and Ethical Education in the Development of Students' Behavior in TahtayKoraroWereda": The Case of Kelebet Elementary School. International Journal of Sustainable Development Research. Vol. 3, No. 6, 2017, pp. 77-84. doi: 10.11648/j.ijsdr.20170306.13.

[14] Shon, J (2015). "Defining civic and citizenship education or what is good citizen?".

[15] Tekeste Negash (2006). "Education in Ethiopia: from crisis to brink of collapse", discussion paper 33 nordiska africkainstitutet uppsala.

[16] Tesfaye Semela, Thorsten Bohl, Marc Kleinknecht (2012). "Civic education in Ethiopian schools: Adopted paradigms, instructional technology, and democratic citizenship in a multicultural context", International Journal of Educational Development 33 (2013) 156-164.

[17] UNDP (2004). "Civic Education: Practical Guidance Note", UNDP, United States.

[18] Vasilveji, B (2009). "Civic education as a potential for developing civil society and democracy; the case Serbia", unpublished master thesis, university of Tromso Norway.

[19] Yamada Shoko (2011). "Equilibrium on Diversity and Fragility: Civic and Ethical Education Textbooks in Democratizing Ethiopia”. Journal of International Cooperation in Education. Vol.14 No.2. 